\begin{tabular}{lcr}
\hline \multicolumn{1}{c}{ A N N A L E S } \\
UNiversitatis & MARIAE CURIE-SKŁODOWSKA \\
LUBLIN - POLONIA & 2020 \\
\hline
\end{tabular}

Uniwersytet Wrocławski, Wydział Nauk Społecznych, Instytut Studiów Międzynarodowych

\author{
PAWEŁ POKRZYWIŃSKI
}

ORCID ID: https://orcid.org/0000-0002-5018-2186

\title{
Rada Jesza jako przyktad instytucjonalizacji ruchu osadniczego w Izraelu
}

The Yesha Council as the Example of the Institutionalization of the Jewish Settler Movement in Israel

\begin{abstract}
ABSTRAKT
Celem artykułu jest przedstawienie działalności Rady Jesza, która po ponad trzech dekadach może zostać uznana za w pełni ukształtowaną i zinstytucjonalizowaną organizację reprezentującą żydowskich osadników na Zachodnim Brzegu. Wytworzyła ona szerokie sieci powiązań i wachlarz działań promujących osadnictwo w kraju i za granicą oraz dąży do uznania żydowskiej obecności na tym obszarze. Autor uznał, że w analizie pomocny będzie nowy instytucjonalizm z naciskiem na sieciowość i racjonalność wyboru. W ukazaniu rozwoju ruchu osadniczego wykorzystano także metodę ilościową. W tekście przedstawiono krótki rys historyczny Rady Jesza, sposoby działania organizacji oraz rozwój żydowskich osiedli w Judei i Samarii. Hipotezę niniejszego artykułu oparto na stwierdzeniu, że Rada Jesza, pomimo iż z początku była związana z radykalną ideologią narodowo-religijną, to stała się ona na przestrzeni lat swojego funkcjonowania zinstytucjonalizowaną organizacją, która rości sobie przez to prawo reprezentacji wszystkich osadników. Przeprowadzona analiza Rady Jesza pozwala stwierdzić, że jest to w pełni zinstytucjonalizowana organizacja, mająca wypracowany szeroki zakres działań i narzędzi pozwalających na realizację celów wewnątrz państwa i poza jego granicami.
\end{abstract}

Słowa kluczowe: Zachodni Brzeg, Judea i Samaria, Rada Jesza, Izrael, Palestyna, osadnictwo żydowskie 


\section{WSTĘP}

Osadnictwo żydowskie ma długą historię. Jego zasięg nie ograniczał się wyłącznie do terenów Zachodniego Brzegu. W przeszłości można wyróżnić tzw. stary i nowy jiszuw ${ }^{1}$. Ten pierwszy dotyczył żydowskiej społeczności zamieszkującej Palestynę za czasów Imperium Osmańskiego do 1881 roku, a jego reprezentanci decydowali się na zamieszkanie tego obszaru ze względów religijnych. Po 1881 roku, kiedy miała miejsce pierwsza alija ${ }^{2}$, a swoją działalność rozpoczynały pierwsze grupy przygotowujące chalucy ${ }^{3}$ do wyjazdu do Palestyny, ideologia narodowa i państwotwórcza zaczęła dominować wśród Żydów przybywających na Bliski Wschód. Po zapoczątkowaniu przez Teodora Herzla ruchu syjonistycznego, osadnictwo w Palestynie stało się głównym punktem programu żydowskiego ruchu narodowego. Po powstaniu Państwa Izrael w 1948 roku kolejnym wydarzeniem mającym wpływ na ruch osadniczy była wojna sześciodniowa z 1967 roku. Wówczas w granicach państwa zalazły się: Strefa Gazy, Półwysep Synaj, Wzgórza Golan oraz Zachodni Brzeg. Następstwem tego był rozwój osiedli na nowo zdobytych terenach, które teoretycznie miały pełnić funkcje obronne i zabezpieczające granice. Znalezienie się w granicach państwa biblijnych terenów Judei i Samarii oraz Synaju wzmocniło ruchy narodowo-religijne i mesjanistyczne nawołujące do zasiedlenia tych obszarów w celu przyspieszenia przyjścia Mesjasza. Również państwo dostrzegło korzyści ekonomiczne i socjalne płynące z rozwoju osadnictwa na Wzgórzach Golan czy Zachodnim Brzegu. W związku z tym instytucje rządowe wraz ze Światową Organizacją Syjonistyczną tworzyły programy wspierające lub inicjujące żydowską obecność na wspomnianych terenach. Wiele partii prawicowych (Cherut/Likud, Israel Beitenu, Ichud Leumi) i narodowo-religijnych (Mafdal, Tchija, Kach, Ha-Bajt ha-Jehudi) wpisało utrzymanie osadnictwa w swoje programy polityczne. Najsłynniejszym pozarządowym ruchem osadniczym był Gusz Emunim ${ }^{4}$. Jednak ze względu na podziały ideologiczne i niespójne wizje dotyczące dalszego działania ruch rozpadł się, a miejsce po nim zajęła Rada Jesza ${ }^{5}$. Organizacja ta współcześnie uważana jest za reprezentanta osadników z Zachodniego Brzegu (do 2005 roku dodatkowo ze Strefy

1 Jiszuw (hebr. יישוב) jest określeniem na społeczność, populację i osadnictwo. Terminem tym nazywa się społeczność żydowską zamieszkującą terytorium Palestyny przed powstaniem Izraela.

2 Alija (hebr. עלייה) to hebrajskie określenie na emigracje Żydów do Palestyny, a po 1948 roku do Izraela. Dosłownie alija oznacza wstąpienie, wznoszenie się lub każdy ruch w górę.

3 Chaluc (hebr. חלוץ) w języku hebrajskim oznacza pioniera. Takim określeniem nazywano pierwszych emigrantów żydowskich w Palestynie.

4 Gusz Emunim (hebr. גוש אמוני ם, pol. Blok Wiernych) był ruchem osadniczo-politycznym utworzonym w drugiej połowie lat 70. XX wieku. Zrzeszał środowiska ortodoksyjne, świeckiej prawicy, narodowo-religijne. Zajmował się promowaniem i lobbowaniem na rzecz osadnictwa na płw. Synaj, Wzgórzach Golan, w Strefie Gazy, Judei i Samarii.

5 Rada Jesza (hebr. מועצת יש" ע, Moecet Jesza). Jesza (hebr. ישזה) to akronim od hebrajskich słów Jehuda, Szomron, Aza (hebr. יהוד, שומרון עז ה), czyli Judea, Samaria, Gaza. W literaturze anglojęzycznej organizacja występuje jako Yesha Council. 
Gazy) oraz instytucję zrzeszającą ich w ramach samorządów lokalnych. Ma ona szeroki zakres działania, począwszy od rozwoju osadnictwa, po promocję turystyki, budownictwo aż po lobbing polityczny. Wydaje się, iż stała się ona najbardziej zinstytucjonalizowaną organizacją reprezentującą osadników na Zachodnim Brzegu.

Należy wspomnieć, że obecność osadników w Judei i Samarii jest wciąż przedmiotem debat i sporów politycznych w Izraelu. Tereny te nie zostały wcielone do Państwa Izrael na drodze prawnej, jak np. Wschodnia Jerozolima (1967) czy Wzgórza Golan (1981). Izraelskie osiedla stanowią również przedmiot zainteresowań naukowców. W Polsce tematykę tę poruszał m.in. Jarosław Jarząbek [Jarząbek 2007: 427-445], Marcin Szydzisz [Szydzisz 2014: 167-180; 2012: 276-286] czy Artur Skorek [Skorek 2012: 55-77]. W literaturze anglojęzycznej temat osadnictwa jest częściej poruszany. Tu należy chociażby przywołać prace Amiego Pedahzura [Pedahzur 2012], Israela Shahaka i Nortona Mezvinsky'iego [Shahak, Mezvinsky 1999], Idith Zertal i Akivy Eldar [Zertal, Eldar 2007] czy też Elishy Efrata [Efrat 2006].

Celem artykułu będzie zaprezentowanie celów i sposobów działania Jeszy oraz tego, jak pod jej przewodnictwem rozwijało się osadnictwo w Judei i Samarii. W tekście dodatkowo podjęto próbę scharakteryzowania relacji pomiędzy Jeszą a izraelską polityką. Posłużono się terminem ,nowy instytucjonalizm”, którym obok formalnych hierarchii, struktur i norm podkreślono formalne aspekty polityki i działalności, interakcje między nimi i zwyczaje oraz postawy [Lowndes 2006: 89-90]. Nowy instytucjonalizm bada także zmiany zachodzące w organizacjach, ich zdolności przystosowania się do otoczenia i realizacji swoich celów. W tym celu autor skorzystał z instytucjonalizmu sieci, który bada, jak działania polityczne są kształtowane przez wspomniane nieformalne zasady, zachowania i powiązania [Lowndes 2006: 94-95]. Dodatkowo w kwestii Rady Jesza przydatny może się okazać instytucjonalizm racjonalnego wyboru, w którym organizacje są systemami, w których jednostki dążą do maksymalizacji zysków i użyteczności [Lowndes 2006: 94-95]. Oprócz tego w artykule zastosowano metodę ilościową w celu ukazania rozwoju osadnictwa na Zachodnim Brzegu, liczby żydowskich mieszkańców i liczby osiedli.

Na podstawie powyższego autor wyróżnił następujące pytania badawcze:

1) Jakie środki działania wypracowała Rada Jeszaw kwestiach osadnictwa?

2) Jak wyglądają relacje pomiędzy izraelską sceną polityczną a Jeszą?

3) Jak wygląda rozwój żydowskiego osadnictwa na Zachodnim Brzegu w okresie istnienia Rady?

Na podstawie wybranych w artykule metod i zaproponowanych pytań badawczych autor zaproponował następującą hipotezę: Rada Jesza, pomimo iż z początku była związana z radykalną ideologią narodowo-religijną, to stała się ona na przestrzeni lat swojego funkcjonowania zinstytucjonalizowaną organizacją, która rości sobie przez to prawo do reprezentacji wszystkich osadników. Dodatkowo szeroko zakrojona działalność Jeszy ma na celu propagowanie osadnictwa w kraju i za granicą, co ma wzmocnić argumentację o uzasadnionej żydowskiej obecności w Judei i Samarii. 


\section{REGULACJE DOTYCZĄCE POWOŁANIA DO ŻYCIA OSIEDLA W JUDEI I SAMARII}

Decyzja o powstaniu legalnego osiedla musi być podjęta na szczeblu rządowym. Władze państwowe, biorąc pod uwagę determinanty związane $\mathrm{z}$ finansowaniem i bezpieczeństwem, decydują, czy okoliczności powstania nie będą zagrażać przyszłym mieszkańcom.

Drugą przesłanką decydującą o powstaniu jest status terenu pod budowę. Musi on mieć nadany tytuł „ziemi państwowej”, czyli terytorium niebędącego własnością Palestyńczyków. Wymóg ten został wprowadzony przez rząd Menachema Begina ${ }^{6}$ po wyroku Sądu Najwyższego Izraela w sprawie wsi Elon More, którą wybudowano nielegalnie na terytorium należącym do Arabów. Działanie takie było niezgodne w świetle prawa Izraela [Shindler 2011: 349].

Trzecim warunkiem jest sporządzenie szczegółowego planu zabudowy. Wymóg ten ma przeciwdziałać niekontrolowanemu rozwojowi nowych osiedli poza wytyczone granice municypalne. Ma to zmusić osadników do przestrzegania określonych wytycznych i planów zagospodarowania przestrzennego [Sason 2005].

Ostatni wymóg to określenie granic planowanego osiedla w prośbie przedłożonej rządowi. Dopiero w sytuacji kiedy rada ministrów zaakceptuje plan regionalny, dowódca wojskowy możne wytyczyć działki oraz ustalić jurysdykcję danego osiedla [Sason 2005].

\section{PRZYCZYNY OSADNICTWA NA ZACHODNIM BRZEGU I JEGO RODZAJE}

Żydzi zamieszkujący Zachodni Brzeg tworzą społeczności narodowo-religijne, ortodoksyjnie, mieszane oraz świeckie. W 2011 roku organizacja Szalom Achszaw ${ }^{7}$ wyliczyła, że $29 \%$ osiedli w Judei i Samarii funkcjonuje jako ultraortodoksyjne [West Bank \& Jerusalem... 2012]. Powyższy fakt może nieco zaskakiwać, zwłaszcza że Żydzi ortodoksyjni, tzw. charedim ${ }^{8}$, nigdy nie uznawali świeckiego syjonizmu. Jednak liczne problemy socjalne społeczności charedim skłaniają ich do zamieszkania na Zachodnim Brzegu. Ich osiedla znajdują się również blisko Zielonej Linii (tzw. Pas Wzgórz Zachodnich i Pas Metropolii Jerozolimyª). Drugą co do wielkości

6 Menachem Begin był przywódcą prawicowej młodzieżówki - Bejtar - w Polsce w latach 30. XX wieku. Od 1944 roku był przywódcą żydowskiej podziemnej organizacji paramilitarnej Irgun w Palestynie. W 1977 roku został pierwszym prawicowym premierem Izraela, przewodnicząc partii Likud.

7 Szalom Achszaw (hebr. שלום עכשי ו, pol. Pokój Teraz) to izraelska organizacja pozarządowa promująca rozmowy pokojowe między Izraelem a Palestyńczykami, przestrzeganie praw człowieka i prawa humanitarnego. Popiera dwupaństwowe rozwiązanie konfliktu.

8 Charedim (hebr. חרדי ם, liczba mnoga od słowa charedi, hebr. חרד) to hebrajska nazwa Żydów ultraortodoksyjnych.

9 Zachodni Brzeg jest podzielony na 3 pasy oraz okręg, jeśli chodzi o lokalizacje osadników. Pas Wschodni to dolina Jordanu oraz wybrzeże Morza Martwego; Pas Górski rozciąga się od zachodnich stoków wzgórz po wschodnie stoki wzgórz dzielących Zachodni Brzeg, osady zbudowane są wzdłuż drogi 
grupę jednostek osadniczych stanowią osiedla określone jako ideologiczne, typowo narodowo-religijne (25\%), które są ulokowane wzdłuż tzw. Pasma Górskiego. Z kolei osiedla sklasyfikowane jako świeckie stanowią 15\% osadnictwa na Zachodnim Brzegu [West Bank \& Jerusalem... 2012]. Są one zlokalizowane w pobliżu Jerozolimy, Zielonej Linii (Pas Zachodni i Pas Metropolii Jerozolimy) oraz wzdłuż doliny Jordanu i Morza Martwego (tzw. Pas Wschodni). Największą liczbę osiedli na Zachodnim Brzegu stanowią te, które są określane mianem mieszanych (31\%) [West Bank \& Jerusalem... 2012]. Ich mieszkańcy są reprezentantami głównie postawy ,jakość życia", w myśl której osiedla stanowią tzw. sypialnie dla ludzi pracujących na co dzień w Tel Awiwie, Hajfie czy Jerozolimie.

Opisując profile osadnictwa oraz jego determinanty, należy wspomnieć o profitach oferowanych obywatelom przez władze, które mają zachęcać do zamieszkania na Zachodnim Brzegu. Organizacja B’Tselem ${ }^{10}$ zauważyła, że osiedla otrzymują liczne ulgi i dopłaty, mimo swojego szybkiego rozwoju oraz dobrej sytuacji ekonomicznej ich mieszkańców [Hareuveni 2010: 37-38 [11 $^{11}$ Co więcej, działania te mają na celu zatrzymanie młodych osadników w miejscu zamieszkania, a także zachęcenie ich do rozwoju swoich społeczności. Pośród oferowanych dodatków można wyróżnić świadczenia:

- mieszkaniowe (ceny niższe niż np. w Tel Awiwie, a także dogodniejsze warunki nabycia lokali oraz ich wyższy standard) ${ }^{12}$,

- edukacyjne (dopłaty do transportu szkolnego, większe zarobki dla nauczycieli oraz pokrycie kosztów wynajęcia przez nich domów) ${ }^{13}$,

- przemysłowe (wsparcie finansowe dla przedsiębiorców ze strony Ministerstwa Handlu i Przemysłu ${ }^{14}$, redukcja opłat za wynajem ziemi pod działalność przemysłową o 69\%, dofinansowania do inwestycji, pokrycie kosztów badań związanych z rozwojem technologii do $60 \%$ ),

- rolnicze (dofinansowania do $25 \%$ do kosztów poniesionych inwestycji, subsydia do agroturystyki, np. winnic i tłoczni oliwy) $)^{15}$.

nr 60 i 458; Pas Wzgórz Zachodnich to teren od zachodnich stoków wzgórz po Zieloną Linię na zachodnie Zachodniego Brzegu; Pas Metropolii Jerozolimy to osiedla połączone z Jerozolimą i tworzące wokół niej pierścień.

${ }^{10}$ B’Tselem (hebr. בצל ם, pol. na podobieństwo) to izraelska organizacja pozarządowa dokumentująca łamanie praw człowieka przez Izrael na Zachodnim Brzegu.

${ }^{11}$ Porównywalna średnia pensja jak w Izraelu, wyższy o 10\% miesięczny dochód gospodarstw domowych niż w kraju, mniejsza liczba bezrobotnych oraz, z racji na wiek osadników, mniejsza liczba emerytów.

${ }^{12}$ Osiedla w Judei i Samarii są finansowane z budżetu, a ministerstwa za to odpowiedzialne oferują granty obniżające koszty nabycia.

${ }^{13}$ Lokalne rady miejskie otrzymują finanse na rozszerzanie działalności naukowej, budowę placówek użyteczności publicznej i naukowej.

${ }^{14}$ B’Tselem obliczyło, że w latach 1997-2001 Ministerstwo Handlu i Przemysłu przeznaczyło 20\% swojego budżetu na te obszary, co dało 237 milionów szekli (NIS).

${ }^{15}$ Za świadczenia rolnicze odpowiada Ministerstwo Rolnictwa oraz specjalny dział Światowej Organizacji Syjonistycznej. Według B'Tselem w latach 2009-2010 na sektor rolnictwa w rejonie Judei i Samarii przeznaczono 143 miliony NIS [Hareuveni 2010: 39-44]. 


\section{RADA JESZA - SAMORZĄDOWY ORGAN OSADNIKÓW WOBEC WYDARZEŃ I DECYZJI POLITYCZNYCH}

Data powstania Rady Jesza pojawia się w niewielu źródłach. Brakuje jej również na oficjalnej stronie internetowej. Idith Zertal i Akiva Eldar za początek funkcjonowania organizacji podają wczesne lata 80 . XX wieku. Jesza, według swoich założeń, realizuje strategiczne założenia syjonizmu. Są nimi umacnianie i rozwój osadnictwa w Judei i Samarii, a także ,walka” o potrzeby osadników, takie jak: budowa dróg, obwodnic czy zapewnienie szczególnych środków bezpieczeństwa. Jesza ma na celu promowanie i rozwijanie osadnictwa przez środki prawnicze, propagandowe, a także polityczne [Zertal, Eldar 2007: 208; Odot Moecet Jesza].

$\mathrm{W}$ latach 80. XX wieku Jesza zajęła czołową pozycję w reprezentowaniu interesów osadników oraz stała się główną organizacją lobbującą na rzecz osadnictwa ${ }^{16}$. Było to możliwe dzięki powolnemu zatracaniu ideologii przez Gusz Emunim, którego członkowie postanowili wstąpić do religijnych i prawicowych partii politycznych. Doprowadziło to do przesunięcia się centrum aktywności politycznej na Radę Jesza, która zaczęła się jawić jako nowa szansa na przedłużenie działalności ruchu osadniczego na Zachodnim Brzegu [Zertal, Eldar 2007: 236-237; Neidle 2013: 494-495].

Momentem krytycznym dla Rady Jesza były rozmowy pokojowe w Oslo oraz zabójstwo premiera Icchaka Rabina. Rada z jednej strony nie akceptowała negocjacji z Palestyńczykami, a z drugiej musiała odciąć się od oskarżeń o popieranie radykalnych środowisk. Wydany na początku 1993 roku Biuletyn do mieszkańców uznał trwający konflikt polityczny za najważniejszy od czasów wyjścia Żydów z Egiptu. Według publikacji, państwo weszło w okres ogólnonarodowego sporu. Jesza planowała upowszechnić kwestię osadnictwa w Izraelu, tak aby utworzyć „narodowy front”, w którym znaleźliby się nawet ludzie niezamieszkujący Judei i Samarii. Po zabójstwie Rabina Moecet Jesza wydała w imieniu wszystkich osadników Deklarację żaloby $i$ wezwanie do narodowego pojednania. Zawarty w niej przekaz miał odciąć Radę od kampanii nienawiści przeciw premierowi [Zertal, Eldar 2007: 144-146]. Następnie Jesza zorganizowała spotkanie „Laudacja i rachunek sumienia”. Zaproszono na nie członków organizacji oraz reprezentantów partii prawicowych i religijnych w celu odcięcia się od powiązań z zabójcą. Dodatkowo uznano, że ruch osadniczy stał się ofiarą porozumień Oslo. Wielu mówców wskazywało za niesłuszne oskarżenia kierowane w stronę religijnych syjonistów [Zertal, Eldar 2007: 153-154].

Kolejnym momentem istotnym dla Rady była decyzja Ariela Szarona o jednostronnym wycofaniu ze Strefy Gazy (2005). Środowiska związane z Jeszą były temu zdecydowanie przeciwne. Uznały one plan premiera za niemoralny i sprzeczny

\footnotetext{
${ }^{16}$ Należy zaznaczyć, że według izraelskiego prawa lobbing w parlamencie może być wyłącznie prowadzony przez posłów zakładających w tym celu specjalne grupy. Mimo to na konsultacje i spotkania mogą być zapraszane osoby z zewnątrz. Zob. [Odot ha-szdulanim].
} 
z izraelską racją stanu. Rozpoczęto natychmiast akcję protestacyjną, mającą wyrazić poparcie dla osadników podlegających wysiedleniu. Jej znakiem były pomarańczowe opaski i wstążki [Newman 2005: 201; 2013; Odot Moecet Jesza]. Kolor ten współcześnie występuje w logach takich partii, jak Ha-Ichud ha-Leumi czy Ha-Bajt ha-Jehudi.

Obecnie w Judei i Samarii Jesza zrzesza 6 rad regionalnych: Szomron (34 miejscowości), Bikaat ha-Jardan (21), Mate Binjamin (45), Gusz Ecijon (14), Megilot Jam ha-Melach (6), Har Chewron (16); 14 rad lokalnych: Oranit (5500 mieszkańców), Alfej Menasze (8200), Elkana (ok. 3500), Efrata (7600), Bejt Arie-Ofarim (2700), Bejt El (900 rodzin), Giwat Zeew (10 000), Har Adar (400 rodzin), Maale Efraim (1800), Emanuel (4000), Kedumim (4300), Kirjat Arba (6500), Karnej Szomron (6400) oraz komitet miejski Hebron (500); a także 4 miasta: Ariel (19 260 mieszkańców), Bejtar Ilit (35 000), Modiin Ilit (60 000), Maale Adumim (38 000) [Arim be-Jesza; Moacot ezorjot be-Jesza; Moacot makomjot be-Jesza].

\section{FORMY DZIAŁALNOŚCI JESZY PROPAGUJĄCE OSADNICTWO}

W ramach swojej aktywności Rada prowadzi działalność edukacyjno-społeczną. Na stronie internetowej organizacja umieszcza materiały związane z historią Izraela i legalnością jego istnienia. Wśród nich znajduje się opracowanie dotyczące historii Ziem Izraela od starożytności po brytyjski Mandat Palestyny. Wyłania się z niego teza, iż Izrael jako twór państwowy w tym regionie jest konceptem wyłącznie żydowskim. Wszystkie inne cywilizacje traktowały Palestynę jedynie jako prowincję swojego terytorium. W opracowaniu pojawia się również stwierdzenie o istnieniu nieprzerwanej obecności Żydów w Judei i Samarii. Historyczne uzasadnienie dla osadnictwa jest podawane na przykładzie Jerozolimy, Hebronu, Sychem (artykuł nie podaje arabskiej nazwy miasta - Nablus) [Erecha-Jehudim: geopolitika we-recifut hitjaszwutit].

Oprócz naukowego podejścia w propagowaniu osadnictwa Jesza prowadzi szeroką działalność multimedialną. Współpracuje ona z portalem Israelszeli (Mój Izrael). Powstał on jako ruch syjonistyczno-narodowy propagujący w internecie idee syjonizmu, w Izraelu i na świecie. Wśród licznych jego celów można wyróżnić wychowywanie zgodnie z wartościami syjonizmu i judaizmu, zwalczanie kampanii antyizraelskich, wspieranie żołnierzy Armii Obrony Izraela oraz promowanie aliji. Portal posiada również konto na serwisach YouTube, Tweeter oraz Facebook [Mi anachnu?].

Drugim serwisem, który współpracuje z Jeszą, jest Efszari (Możliwy). Portal zakłada, że przed 1967 rokiem nie istniało państwo o nazwie Palestyna. Tereny Judei i Samarii były częścią Jordanii, która w trakcie tej wojny sześciodniowej poniosła porażkę. Według twórców portalu, Zielona Linia nie była nigdy granicą międzypaństwową, a jedynie linią zawieszenia broni między Izraelem a Jordanią. Oprócz tego prawa Żydów do Zachodniego Brzegu oparte są na historii i porozumieniach 
międzynarodowych. Obszar ten stanowi głębię strategiczną Izraela i jest największym izraelskim podziemnym zbiornikiem wody w regionie [Jehuda we-Szomron merkaz...].

W swojej działalności Jesza promuje i angażuje się w rozwój turystyki w Judei i Samarii. Na stronie internetowej organizacja zamieszcza informacje dotyczące spotkań kulturalnych, świąt religijnych, miejsc wartych zobaczenia, noclegów czy szlaków turystycznych [Tajerut ba-Jesza]. Rada zajmuje się także wydawaniem własnego czasopisma Jesza szeli (hebr. ש" על שלי, Moja Jesza). Znajdują się w niej artykuły dotyczące spraw i problemów społeczności osadniczych. Oprócz tego można w nich znaleźć reklamy oraz ogłoszenia związane ze sprzedażą domów. Jesza zajmuje się także sprzedażą aut o podwyższonym poziomie bezpieczeństwa. W tym celu na swojej stronie umieściła procedury i wytyczne izraelskiego Ministerstwa Transportu, które określają warunki, jakie należy spełnić, aby ubiegać się o dofinansowanie do zwiększenia ochrony auta, np. wymianę szyb szklanych na plastikowe [Rechewimmemuganim; Nahlej migun].

Rada współpracuje z Ruchem Osadniczym Amana, który reprezentuje osadnicze lobby budowlane. Powstał on w 1978 roku w celu budowy nowych osiedli i rozwoju już istniejących na obszarze Wzgórz Golan, Galilei, Judei i Samarii i pustyni Negew. Instytucja rozszerza swoją działalność o szkolenie lokalnych wspólnot osadniczych $\mathrm{w}$ dziedzinie przedsiębiorczości, absorbcji nowych imigrantów, pomocy w tworzeniu planów osadniczych i zagospodarowania przestrzeni, pozyskiwaniu funduszy z diaspory i organizacji międzynarodowych. Amana chce stworzyć szeroki front poparcia składający się z osób świeckich oraz ortodoksyjnych, w różnym przedziale wiekowym, o różnych pozycjach społecznych [Tnuat hitjaszwut Amana; Jeud ha-tnua $]^{17}$.

\section{ROZWÓJ OSADNICTWA W JUDEI I SAMARII}

Na podstawie statystyk prowadzonych przez B'Tselem można zauważyć, że od 1967 roku do 1995 powstało 121 jednostek osadniczych na Zachodnim Brzegu. Liczba ich mieszkańców waha się od kilkudziesięciu (Niran - 85 osób na 2015 rok) do kilkudziesięciu tysięcy mieszkańców (największe Modiin Ilit - 64179 osób oraz Beitar Ilit - 49343 w 2015 roku). W całej Judei i Samarii w 2015 roku mieszkało 588136 osadników, a tylko w samej wschodniej części Jerozolimy mieszkało ich 205 220. Od 1995 do 2005 roku na Zachodnim Brzegu powstało 96 osiedli (w tym 5 legalnych i 91 nielegalnych) [Statistics on Settlements and Settler Population]. Po porozumieniach z Oslo Jesza nie ograniczyła swojej aktywności wyłącznie do

\footnotetext{
${ }^{17}$ Ami Pedahzur stwierdził, że dzięki powiązaniu z Gusz Emunim Ruch Osadniczy Amana stał się głównym beneficjentem funduszy Agencji Żydowskiej i izraelskich ministerstw na rozwój i budowanie osiedli w latach 70. i 80. XX wieku [Pedahzur 2012: 54].
} 
turystyki, promocji i edukacji. Jej główną działalnością był dalej rozwój osiedli na obszarze Zachodniego Brzegu. W roku 2002 roku, wraz z Ministerstwem Spraw Wewnętrznych organizacja podała, że liczba izraelskich mieszkańców w Judei, Samariii w Strefie Gazy wyniosła 214000 osób. Według wyliczeń obu instytucji jest to o 5,2\% więcej niż w 2001 roku. Od początku rozmów w Oslo liczba mieszkańców zrzeszonych w Radzie zwiększyła się o 8\%. Wielkości te nie są duże, jednak w perspektywie poszczególnych miast mogą stać się istotne. W latach 2001-2002 do Bejtar Ilit przeprowadziło się 1600 nowych mieszkańców, natomiast rada regionalna Binjamin zanotowała wzrost o 8\% [Yesha Population Grows By 5.2\%] ${ }^{18}$. W roku 2014 izraelska internetowa gazeta „Times of Israel” opublikowała artykuł podający kolejne dane dotyczące osadników na Zachodnim Brzegu. W ciągu samej pierwszej połowy 2014 roku liczba jego izraelskich mieszkańców urosła o 2\%, z 374469 osób do 382 031. Według Daniego Dayana ${ }^{19}$ przyrost ten był spowodowany wysoką dzietnością wśród osadników, czynnikami finansowymi, warunkami socjalnymi. Z kolei miejscowości uważane za ideologiczne, znajdujące się w głębi Zachodniego Brzegu, rozwinęły się o 3,8\% [Federman 2014]. Wskazuje to, że osadnictwo motywowane przekonaniami politycznymi nie straciło na popularności od 1995 roku.

Należy także zwrócić uwagę na informacje podawane przez organizację Szalom Achszaw w sprawie nielegalnych osiedli. Rząd Izraela bardzo często legalizuje je jako nowe dzielnice istniejących już jednostek. Potwierdza to Raport Sason z 2005 roku. Talia Sason stwierdziła w nim, że rady regionalne zdają sobie sprawę z istnienia niezgodnych z prawem osiedli, jednak nie podejmują żadnych działań, żeby temu zapobiec [Sason 2005; Geulat Zion: Another New Settlement]. W momencie kiedy dochodzi do ewakuacji nielegalnych osiedli, rząd postanawia przesiedlić mieszkańców do innych miejscowości lub tworzy nowe położone nieopodal. Najlepszym tego przykładem jest ewakuacja Amony, której legalność zakwestionował Sąd Najwyższy Izraela i nakazał jej likwidację. Jak podał Szalom Achszaw, rząd Benjamina Netanjahu postanowił stworzyć dla ewakuowanych mieszkańców nowe osiedla: Geulat Cijon (2,5 km od istniejącego już Szilo), Szwut Rachel Mizrach (1 km od istniejącego Szwut Rachel i 2 km od Szilo) oraz Amichaj (ok. 2 km od Szwut Rachel) [Lieberman 2017; Jurisdiction of The New...].

Kolejnym istotnym faktem jest liczba zbudowanych domów dla osadników. Dane „Times of Israel” na rok 2013 wskazują, że liczba budynków zwiększyła się o 123\% w stosunku do roku poprzedniego (w 2012 liczba ta wyniosła 1133, a w 2013 -2534). W tym samym artykule podano, że na całym południu kraju liczba domów zwiększyła się o $12 \%$, Hajfie o 8\%, a w północnym Izraelu tylko o 1\% [Miller, Ben Zion 2014]. Nowe konstrukcje wiążą się także z zapotrzebowaniem na nowe sieci dróg,

${ }^{18}$ W roku 2001 w Bejtar Ilit było 17300 mieszkańców, natomiast w 2002 roku 20 200. Z kolei w Maale Adumim w 2001 roku było 25800 mieszkańców, a w 2002 roku 26500 [Statistics on Settlements and Settler Population].

${ }^{19}$ Dani Dayan jest byłym przewodniczącym Moecet Jesza, w 2015 roku ambasadorem Izraela w Brazylii, a w 2016 roku został mianowany Konsulem Generalnym Izraela w Nowym Jorku. 
szkoły, przedszkola czy tereny rekreacyjne dla osadników. Raport organizacji Szalom Achszaw wskazuje, że w 2015 roku rozpoczęto budowę 1800 nowych domów, z czego około $80 \%$ z nich znajduje się na terenach, które Izrael zobowiązał się oddać Palestyńczykom. Co więcej wzniesiono także 63 budynki użyteczności publicznej (szkoły, synagogi, przedszkola). Miasta, które rozbudowano najbardziej, to Modiin Ilit (179 domów), Ariel (133), Kochaw Jaakow (105), Bejt Choron (54), Jakir (51) [No Settlement Freeze... 2016: 1-8]. W 2018 roku organizacja wydała raport dotyczący osadnictwa na Zachodnim Brzegu (z pominięciem wschodniej Jerozolimy) za rok poprzedni. Wynika z niego, iż w 2017 roku liczba budowanych domów (ok. 2800) była większa o 17\% niż średni roczny wynik od 2009 roku. Zaczęto wznosić 68 budynków użyteczności publicznej oraz 69 konstrukcje przemysłowe lub rolnicze. Ogłoszono także przetargi na 3154 nowe domy, co według wyliczeń jest najwyższą liczbą na Zachodnim Brzegu od 20 lat [Peace Now's Annual Settlement Construction Report for 2017: 1]. Dla przykładu w miejscowości Efrat rozwijają się dodatkowe dwa sąsiedztwa (292 domy), a w ortodoksyjnym Beitar Ilit zbudowano nową dzielnicę (Beitar Ilit C - 270 domów). W 2017 roku komitety rządowe odpowiedzialne za osadnictwo spotkały się 4 razy, akceptując 88 planów rozwoju, 6742 nowe domy w 59 różnych osiedlach. Dla porównania w 2015 roku były to tylko 1732 domy, a rok później 2613 [Peace Now's Annual Settlement Construction Report for 2017: 3-4].

\section{ZAKOŃCZENIE}

Powyższa analiza wskazuje, jak przez ponad trzy dekady Rada Jesza wykrystalizowała swoje cele, ukształtowała strukturę, zbudowała wpływy polityczne i przyczyniła się do rozwoju osadnictwa. Wszystko to dokonuje się przy ciągłej obecności reprezentantów skrajnych postaw wewnątrz Jeszy. Przez swoją instytucjonalizację stała się organizacją, która pozwala na maksymalizację zysków dla wszystkich reprezentowanych miejscowości. Wskazuje to na dynamiczne pojęcie instytucji, która cały czas dopasowuje swoje cele i działania do warunków otoczenia, w jakim musi funkcjonować. Historia pokazuje, w jak elastyczny sposób Jesza musiała reagować na zmiany w otoczeniu. Porozumienia z Oslo okazały się dla niej wymagającym wyzwaniem. Członkowie organizacji zauważyli, że polityka rządu, która do lat 90. XX wieku charakteryzowała się wsparciem osadnictwa lub przyzwoleniem na jego rozwój, przeminęła. Podjęcie rozmów z Palestyńczykami wymusiło zmianę sposobów działania. Z jednej strony Jesza musiała pokazać swoim członkom, że nadal reprezentuje osadników i staje w obronie ich interesów. $Z$ drugiej natomiast należało stanowczo odciąć się od ekstremistycznych środowisk narodowo-religijnych. W celu promowania obecności żydowskiej na Zachodnim Brzegu Jesza stara się dotrzeć do obywateli Izraela przez rekreację, turystykę, edukację historyczną, sposoby, które bezpośrednio nie są związane z ideologią, czyli można je uznać za podprogowe. Dzięki takim działaniom Rada Jesza buduje również więzi społeczne 
między osadnikami, kreując wśród nich poczucie wspólnoty celów i potrzeb. Można zatem mówić w tym przypadku o zakorzenieniu się organizacji wśród osadników.

Ewolucja Rady odzwierciedla zmiany, jakie zaszły w ruchu osadniczym. Działalność motywowana głównie ideologią przekształciła się w pragmatyzm, kalkulacje polityczne i budowanie sieci szerokich powiązań. Przykładem tego jest wspomniana wcześniej osoba Daniego Dayana, a także Pinchasa Wallersteina. Ten drugi w październiku 2017 roku został mianowany przez premiera Netanjahu na przewodniczącego rządowego komitetu ds. legalizacji nieuznawanych społeczności Judei i Samarii. Był on niegdyś działaczem ruchu narodowo-religijnego i jest przeciwnikiem rozmów pokojowych [Levi 2017]. Innym przykładem politycznych wpływów Jeszy jest decyzja ministra obrony Awigodra Liebermana z 2018 roku o przyznaniu 6 milionów dolarów na rozwój społeczności osadniczej w rejonie Hebronu [Israel approves $\$ 6$ million...]. W tym miejscu należy zaznaczyć, że osadnictwo na Zachodnim Brzegu rozwijało się podczas rządów lewicy oraz prawicy. Jednak to w tym drugim przypadku działacze Jeszy otrzymują największe wsparcie, środki pomocowe oraz akceptację na rozwój osiedli.

Wielu przedstawicieli Rady bierze udział w organizowanych w Stanach Zjednoczonych konferencjach na temat legalności osiedli, rozciągania izraelskiego prawa cywilnego na Zachodni Brzeg i prób ewentualnej aneksji Strefy C. Administracja Donalda Trumpa zorganizowała kilka oficjalnych spotkań z przedstawicielami Jeszy w celu przedyskutowania przyszłości osadnictwa na Zachodnim Brzegu [Lazaroff 2018; In un precedented session... . . Wskazuje to na dużą dynamikę, jaką charakteryzuje się Jesza, która chce promować swoje postulaty nie tylko w kraju, ale i zagranicą.

Podział terytorialny oraz przyrost liczby mieszkańców wskazują na rozbudowaną strukturę organizacji, szeroki zakres zadań, jaki ma spełniać Rada, oraz na jakość ofert kierowanej do Izraelczyków przez Jeszę. Podział na rady regionalne, rady lokalne oraz miasta uwidacznia daleko idące sformalizowanie ruchu osadniczego, który stworzył samorządne władze stojące na straży jego potrzeb. Potwierdza to zatem hipotezę, iż Rada Jesza przeprowadziła głęboką instytucjonalizację ruchu osadniczego, tworząc niezbędne sieci powiązań. Zapewnia to ciągły rozwój żydowskich miejscowości w Judei i Samarii, wymuszając jednocześnie na rządzie ciągłą troskę o nie.

\section{BIBLIOGRAFIA}

Arim be-Jesza, http://www.myesha.org.il/?CategoryID=171 (dostęp: 11.10.2018).

Efrat, E. 2006. The West Bank and Gaza Strip: A Geography of Occupation and Disengagement, London-New York.

Erec ha-Jehudim: geopolitika we-recifuthitjaszwutit, http://www.myesha.org.11/?CategoryID=336\&ArticleID $=5616$ (dostęp: 12.10.2018).

Federman, J. 2014. West Bank settler group boasts rapid growth, https://www.timesofisrael.com/west-banksettler-group-boasts-rapid-growth/ (dostęp: 13.10.2018). 
Geulat Zion: Another New Settlement, http://peacenow.org.il/en/geulat-zion-another-new-settlement (dostęp: 13.10.2018).

Hareuveni, E. 2010. By Hook and by Crook. Israeli Settlement Policy in the West Bank, Jerusalem.

In unprecedented session, settler leaders meet Trump's envoy, https://www.timesofisrael.com/in-unprecedented-session-settler-leaders-meet-trumps-envoy/ (dostęp: 13.10.2018).

Israel approves \$6 million expansion of Jewish West Bank settlements near Hebron, https://www.i24news. tv/en/news/israel/186337-181014-israel-approves-6-million-expansion-of-jewish-west-bank-settlements-near-hebron (dostęp: 13.10.2018).

Jarząbek, J. 2007. Żydowskie osadnictwo na Zachodnim Brzegu Jordanu, [w:] Wybrane problemy badań wschodnich, Z.J. Winnicki, W. Baluk, G. Tokarz (red.), Wrocław, s. 427-445.

Jehuda we-Szomron merkaz ha-Am ha-Jehudi be-kol ha-et ha-atika, http://www.efshari.co.il/?q=node/13 (dostęp: 12.10.2018).

Jeud ha-tnua, http://www.amana.co.il/?CategoryID=28\&ArticleID=51 (dostęp: 12.10.2018).

Jurisdiction of The New Settlement "Amihai" Approved, http://peacenow.org.i1/en/jurisdiction-new-settlement-amihai-approved (dostęp: 13.10.2018).

Lazaroff, T. 2018. Settler Leader Talks West Bank Annexation in Washington, https://www.jpost.com/ Arab-Israeli-Conflict/Settler-leader-talks-West-Bank-annexation-in-Washington-544418 (dostęp: 15.10.2018).

Levi, T. 2017. Pinchas Wallerstein to head outpost regulation committee, https://www.israelnationalnews. com/News/News.aspx/237251 (dostęp: 13.10.2018).

Lieberman, O. 2017. Amona evacuation complete as Israel police remove remaining protesters, https:// edition.cnn.com/2017/02/02/middleeast/israel-evacuation/index.html (dostęp: 13.10.2018).

Lowndes, V. 2006. Instytucjonalizm, [w:] Teorie i metody badawcze w naukach politycznych, D. Marsh, G. Stoker (red.), Wydawnictwo Naukowe PWN, Kraków, s. 89-109.

Mi anachnu?, http://myisrael.org.il/ (dostęp: 12.10.2018).

Miller, E., Ben Zion, I. 2014. Settlement construction more than doubled in 2013, https://www.timesofisrael. com/settlement-construction-more-than-doubled-in-2013/ (dostęp: 13.10.2018).

Moacot ezorjot be-Jesza, http://www.myesha.org.il/?CategoryID=172 (dostęp: 11.10.2018).

Moacot makomjot be-Jesza, http://www.myesha.org.il/?CategoryID=174 (dostęp: 11.10.2018).

Nahlej migun, http://www.myesha.org.il/?CategoryID=380\&ArticleID=7046 (dostęp: 12.10.2018).

Neidle, J. 2013. Locating the Power of the Settler Movement, „Journal of Politics \& International Studies”, vol. 9, s. 481-519.

Newman, D. 2005. From "hitnachalut" to "hitnatkut": The Impact of Gush Emunim and the Settlement Movement on Israeli Society, ,Israel Studies”, vol. 10, no. 3, s. 192-224. DOI: 10.1353/is.2005.0132.

No Settlement Freeze, Especially Not in Isolated Settlements 2015 in the Settlements, „Settlement Watch - Peace Now" 2016.

Odot ha-szdulanim, https://main.knesset.gov.il/About/Lobbyist/Pages/LobbyistAbout.aspx (dostęp: 11.10.2018).

Odot Moecet Jesza, http://www.myesha.org.il/?CategoryID=167 (dostęp: 11.10.2018).

Peace Now's Annual Settlement Construction Report for 2017, „Settlement Watch - Peace Now” 2018.

Pedahzur, A. 2012. The Triumph of Israel's Radical Right, Oxford University Press, New York.

Plan Promoted for a New Settlement for the Amona Settlers, http://peacenow.org.il/en/plan-promoted-newsettlement-amona-settlers (dostęp: 13.10.2018).

Rechewim memuganim, http://www.myesha.org.1//?CategoryID=380 (dostęp: 12.10.2018).

Sason, T. 2005. Summary of the Opinion Concerning Unauthorized Outposts, http://www.mfa.gov.il/ $\mathrm{mfa} /$ aboutisrael/state/law/pages/summary\%20of\%20opinion\%20 concerning\%20unauthorized $\% 20$ outposts\%20-\%20talya\%20sason\%20adv.aspx (dostęp: 10.10.2018).

Shahak, I., Mezvinsky, N. 1999. Jewish Fundamentalism in Israel, London.

Shindler, C. 2011. Historia wspótczesnego Izraela, Książka i Wiedza, Warszawa. 
Skorek, A. 2012. Wpływ radykalnych grup religijnych osadników żydowskich na konflikt bliskowschodni, [w:] Bezpieczeństwo narodowe i międzynarodowe w obszarze Bliskiego Wschodu i Pótnocnej Afryki (MENA) u progu XXI wieku, R. Bania, K. Zdulski (red.), Łódź, s. 55-77.

Szydzisz, M. 2014. Polska polityka wobec stron konfliktu izraelsko-palestyńskiego po przystapieniu Polski do Unii Europejskiej, „Dyplomacja i Bezpieczeństwo”, nr 1, s. 167-180.

Szydzisz, M. 2012. „Tę ziemię dat nam Bóg”: wplyw czynnika religijnego na postępowanie Izraela na terytoriach okupowanych (działalność ruchu Gusz Emunim), [w:] Religia w stosunkach międzynarodowych, A. M. Solarz, H. Schreiber (red.), Warszawa, s. 276-286.

Statistics on Settlements and Settler Population, https://www.btselem.org/download/settlement_population. xls (dostep: 13.10.2018).

Tajerut ba-Jesza, http://www.myesha.org.il/?CategoryID=183 (dostęp: 12.10.2018).

Tnuat hitjaszwut Amana, http://www.myesha.org.il/?CategoryID=182 (dostęp: 12.10.2018).

West Bank \& Jerusalem Map. The Settlements: The Biggest Threat To A Two-State Solution, https://settlementwatcheastjerusalem.files.wordpress.com/2012/04/settlements_map_eng.pdf(dostęp: 10.10.2018).

Yesha Population Grows By 5.2\%, https://www.israelnationalnews.com/News/News.aspx/16167 (dostęp: 13.10.2018).

Zertal, I., Eldar, A. 2007. Lords of the Land: The War for Israel's Settlements in the Occupied Territories, 1967-2007, Public Affairs, New York.

\section{THE YESHA COUNCIL AS THE EXAMPLE OF THE INSTITUTIONALIZATION OF THE JEWISH SETTLER MOVEMENT IN ISRAEL}

Abstract: The aim of the article is to show an activity of the Yesha Council which, after three decades, became a fully shaped and institutionalized organization. Nowadays the Yesha is representation of all the Jewish settlers in the West Bank. The organization created wide networks of connections and actions to promote settlement in the State of Israel and to legitimize Jewish presence in the Judea and Samaria. The author used the new idea of institutionalism to describe the Yesha Council actions. Special emphasis was put on the networking and rational choice institutionalism. Also, the quantitative method was helpful in describing the development of the settler movement. In addition, the article briefly describes the history of the Yesha and the way it functions.

Keywords: the West Bank, Judea and Samaria, the Yesha Council, Israel, Palestine, Jewish settlement 


\section{BIOGRAM}

Paweł Pokrzywiński, mgr bezpieczeństwa międzynarodowego, lic. judaistyki, doktorant w Instytucie Studiów Międzynarodowych Wydziału Nauk Społecznych Uniwersytetu Wrocławskiego. W kręgu zainteresowań badawczych znajdują się: syjonizm rewizjonistyczny i narodowo-religijny, osadnictwo żydowskie na Zachodnim Brzegu Jordanu, izraelskie partie prawicowe, polityka wewnętrzna Izraela. Kontakt e-mail: pa.pokrzywinski@gmail.com. 